解 説

\title{
被 覆された半導体電極
}

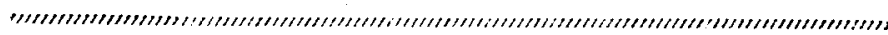

$\square$ 矢 沢 一 彦*

Kazuhiko YAZAWA

\section{1 まえがき}

半導体の光電極反応を利用して，水を分解して水素を 作り，交たは電力を得る技術は，太陽エネルギ一利用の 観点から大きな魅力がある。

この技術には当面の主要な問題点が三つある.

（1）太陽エネルギ一の高い利朋効率を得ること.

（2）セルが長寿命であること（水溶液中で電極が動 作時に溶解したり，表面が酸化・変質したりせぬ こと,その他)

（3）外部補助電源なしで動作可能，にすること（電 極が $n$ 型半導体の場合, フラットバンド電位が水 素発生電位よりも，負である

の三点であって，これらの要求をす心゙て満たすような半 導体電杫が求められている。

実は，このうちどの一つをとっても，仲々の問題であ る。その上，さらにやっ介なことに（1）と（2）の要求 は，互背反する，と言う一般的な傾向がある。すなわ ち, 従来知られている材料関する限りでは, 太陽光ス ペクトルの全域にわたる広範囲の波長領域の光に感度を もつ(禁止帯幅 $E_{\mathrm{G}}$ の小さな) 半導体電極仙, 動作時に 溶液に溶解したり, 酸化変質したりするし, 逆に溶液中 で安定な半導体は $E_{\mathrm{G}}$ が大きく, 紫外域に近いごく短波 長の光にしか応答しないので，太陽スペクトルの利用効 率が悪い.

そこで, 問題の対策として，新しい優れた性質をもつ 半導体材料を探し求めることはもちろんだが，关の他に もいくつかの方法が考えられている。たとえば， $E_{\mathrm{G}}$ が 大きく溶液中で安定な半導体索使用するとき，その有感 波長带域を拡大するために液中に结素を加えたり，また 注半導体自身に各種の不純物元素定添加することが検討 された。また， $E_{\mathrm{G}}$ の小さな半導体の溶解を防ぐため， 溶液中に適当な酸化・還元系を入れる之か，半導体の表 面を金属の薄膜で被膜して保護することも試みられた。

これらの試みのあるものは，それ孙り效果がありまた あるものは無効であることが大体判ったが，いずれも現 在熱心な研究が続行されている.

本文の主題である「被覆された半導体電極」すなわ

*電気通信大学（厂182 束京都調布市調布ケ厌 1-5-1)
ち，基体半導体を，同種または異種の半導体薄膜で被覆 した構造の電極を用いることもこのような試みの一つで めって，ここでは，われわれのグループの仕事を中心に 紹介したい。

\section{2 モット・バリア型構造電極 ${ }^{12}$}

半導体に吸収された光エネルギ一の利用効率を上げる にはどうしたらよいかを，考えてみよう。

図 1 は $n$ 型半導体を電解質溶液汇浸した場合の, エネ ルギー・バンド図である。

溶液側加半導体表面に, $E_{\mathrm{G}}$ 以上の光子エネルギー をもつ光を入射する之，これ吸収されて，伝導電子上 正孔を生しる.そして空閒電荷層内（および，そこから 拡散距離 $L_{\mathrm{D}}$ 以内）に生じた正孔は，空閒電渮層内の電 位こう配により半導体表面に押出されて，電極反忘に寄 与する.が, 半導体のより奥深い部分で発生した正孔は 表面にたどりつくことなく，電子と再結合して消滅す る.

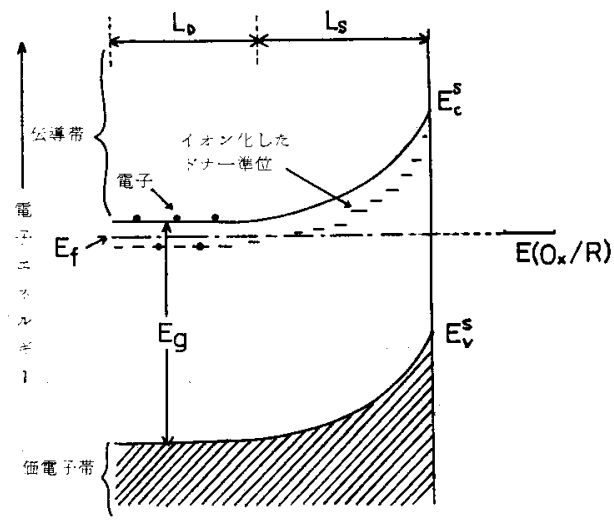

図 $1 n$ 型半導体-電解質溶液界面の エネルギーバンド図

入射光のエネルギーををだなく活かすためには発生し た正孔を全部，半導体表面に集好るらにしなければな らない。つまり，できるだけ（光の侵大染さ以上に）空 間電荷層の厚さ $\left(L_{\mathrm{S}}\right)$ を厚くする必要がある。( $\left(L_{\mathrm{S}}\right.$ 注 ドナー密度 $N_{\mathrm{D}}$ の平方根に反比例するから), このため 
には $N_{\mathrm{D}}$ を小さくしなければならない，一方， $N_{\mathrm{D}}$ を 小さくすると半導体の抵抗が大きくなり，電極特性が悪 くなる。

このジレンマを避けるためのくふらがモットバリア型 構造電極 (M.B.E.) である. $N_{\mathrm{D}}$ の大きな $\mathrm{TiO}_{2}$ の表面 飞 $\mathrm{N}_{\mathrm{D}}$ の小さな $\mathrm{TiO}_{2}$ の薄膜を形成した，この M.B.E. のバンドは図 2 (b) の上うになり，表面化被覆をもた ない通常の $\mathrm{TiO}_{2}$ 電極 (ショットキーバリア型電極: S.B.E.) (a) と電位こう配の形状が異なる。

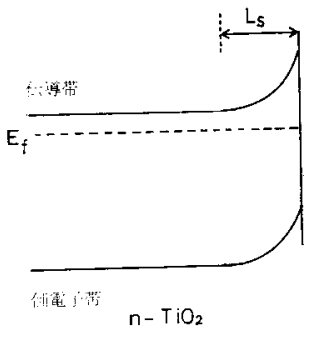

(a)

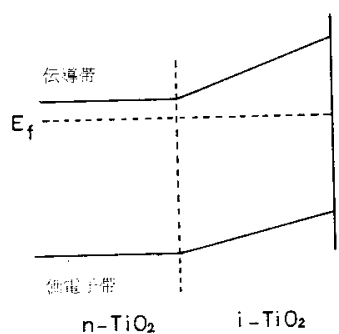

(b)
図 $2 \mathrm{TiO}_{2}$ 電極 (a) とモット・バリア型構造電極 (b) のエネルギー・バンド

この構造では, 正孔を集めるための内部電界領域の厚 さを, 基体半導体の比抵抗亡別個に, 独立に定め, 厚く 作ることができる。

M.B.E. は，たとえば以下に述べる二重処理法で作る ことができる。すなわち，単結晶 $\mathrm{TiO}_{2}$ を，まず $900^{\circ} \mathrm{C}$ で 6 時䦎程度真空還元を行な $5 と, ~ n$ 型半導体になる. 次にこれ酸素らん团気中で $600^{\circ} \mathrm{C}, 5 \sim 10$ 分間の熱処 理を行なって，絶縁性の表面膜を作る(この例示した条 件で注約 $300 \AA ̊$ の厚さの膜ができる). 最後にこの試料 を 1 分間，フッ酸中で処理し，表面活性点を形成するこ

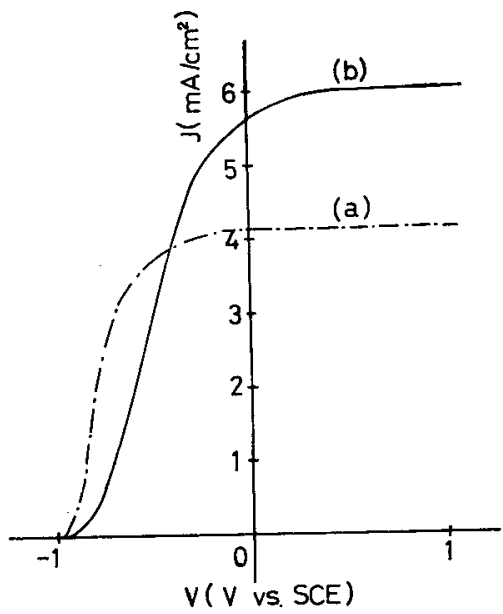

図 $3 \mathrm{TiO}_{2}$ 電極 (a) とモット・バリア型 構造電極 (b) の電流-電位特性
とにより電極ができ上る.

このようにして作った電極の光電流・電位特性は，図 3 のようになり，その飽和電流值は，単なる $\mathrm{TiO}_{2}$ の電 極に比心゙て増大していることが分る。

\section{3 ヘテロ接合型複合電極 ${ }^{2)}$}

半導体電極は， $E_{\mathrm{G}}$ できまる臨界波長より短汃い波長 領域の光に対しての名有效である. したがって，太陽光 の利用効率を上げるためには，できるだけ $E_{\mathrm{G}}$ が小さく て，可視域全域汇わたり光電流感度をもたせることが望 ましい。しかし，ま沉がきにも述べたよらにこの要求事 項（1）を，他の (2)，（3）と同時に満足するような, 半導体電極莸作るこにはかなり難しそらである。そこで 単一の半導体にこれらすべての性質を期待することをや め大，二種類以上の罢なった材料を組合せることによ り，問題を解決することが考光られる。

た上えば， $E_{\mathrm{G}}$ の小さな半導体の表面を，溶液中でも 安定な半導体の薄膜で被膜したら，といらことは容易に 思以っくことである．現在まで，最も安心して使える材 料は $\mathrm{TiO}_{2}$ である. その薄膜を用いて, Si や GaAs, $\mathrm{InP}, \mathrm{CdS}$ などの $E_{\mathrm{G}}$ の小さな半導体を被膜して用いる ことが，いくつかのダループによって試みられたが，成 功しなかった，この構造の電極では，有感波長領域を長 波長まで払げること汸できなかったのである。

バンドキャップの罣なる二種類の半導体の接合(ヘテ 口接合）を用いた複合電極のエネルギーバンド図を図 4 に示す，一般的には図 4 (a) のよ5な形になり，伝導帯 端も価電子带端もともに，接合面で不連続が生じ，さら にそこには界面準位汸生じる．この場合，光によって内 側の半導体内で正孔湆生成されても，それは外側の半導 体を通って電極表面に現われることはできない，おそら く，上に述へたた $\mathrm{TiO}_{2}$ で被覆した電極が，期待どおりに 長波長域の感度をもたなかったのは，(a)のよらなバン ド形状になっていたためであるら。バンドの理想として は，図4(b) の上らな形になることであって，もしこの

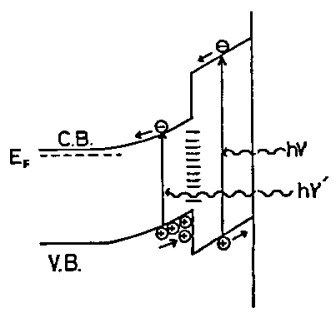

(a)

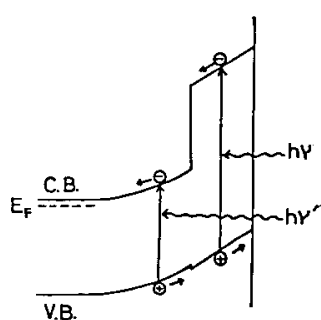

(b)
国 4 ヘテロ接合

(a) :一般の場合

（b）：価電子带端が連続した場合 


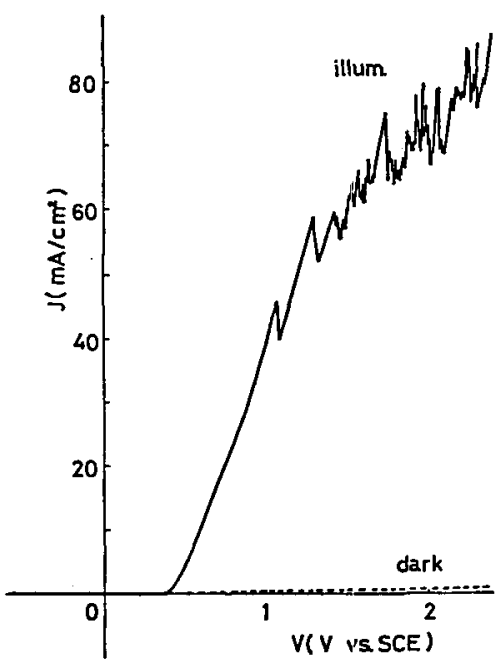

図 $5 \mathrm{Si}$-酸化鉄・ヘテロ接合剡複合電極の電 流一電位特性（酸化鉄の膜厚方゙薄い場合）

ように価電子帯端が連続的につながるなら，内側で発生 した正孔も電極表面に到達し，光電流に寄与することか゚ できる。

そのバンド構造がこのような形になっているらしい， と思われる一例として，基体半導体としての Si を酸化 鉄の薄膜で被覆した，複合構造電極について述へる。

表面を被覆する酸化鉄の膜厚が比較的薄い電極の電 流-電位特性の一例を図 5 に示す。この場合の膜厚は $200 \AA$ である. 点線湆電流を示している. 光電流のゆ らぎは( $1 \mathrm{~W} / \mathrm{cm}^{2}$ の白色光照射により)電極表面から気 胞が激しく発生し，光電流が変動することに因るもので ある.光電流は約 $0.35 \mathrm{~V}$ (vs. SCE) から立上がり，約 $2 \mathrm{~V}$ 以上で飽和するような傾向を示す．飽和電流值ほ約 $90 \mathrm{~mA} / \mathrm{cm}^{2}$ で同じ光源を用いて $\mathrm{TiO}_{2}$ 電極を使用した 場合の 100 倍近い值である.この試料の $2 \mathrm{~V}$ (vs. SCE) における光電流の波長依存性を図 6 に示寸，図の縦軸に 将量子效率をとってある.光応答は $250 \mathrm{~nm}$ 加ら 1,140 $\mathrm{nm}$ にわたって分布しており. 特に $480 \mathrm{~nm}$ から $850 \mathrm{~nm}$ にかけては，量子效率が $80 \%$ に達している。 $\mathrm{TiO}_{2}$ 上

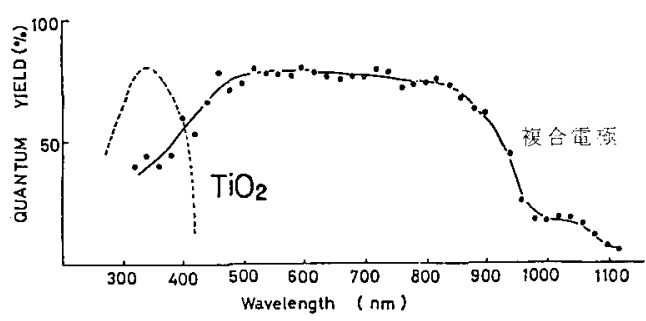

悯 $6 \mathrm{Si}$-酸化鉄・ヘテ口接合型複合電極の光電流 の波長依存性（酸化鉄の鹊厚が薄い場合）
比較して，有効波長領域が大幅に拡大されたことが分る う.この電極の飽和電流值が $\mathrm{TiO}_{2}$ に比べて大幅に増大 したのはこうして, 光源エネルギーの利用率が増したた めである。吸収端の $1,140 \mathrm{~nm}$ は Si のバンドギャップ $1.1 \mathrm{eV}$ に対応している。

次に，酸化鉄の膜厚が比較的厚い場合の例として，膜 厚が $1.6 \mu \mathrm{m}$ の試料の光電流-電位特性を図 7 に示す. 図 5 の薄い酸化膜の試料の場合と比較して, 顕著な違い は, 光電流の立上がり電位が $-0.3 \mathrm{~V}$ とな, 約 $0.7 \mathrm{~V}$ 負にシフトしていることである．また電位上昇にともな う電流の増加割合が薄い酸化膜試料よりかなりゆるやか となっている. 非常に高い正電位（+7 V 以上）では， 電流はやはり飽和する傾向が見られる. 飽和電流值は酸 化膜の厚さの増加につれて，減少する傾向がある。

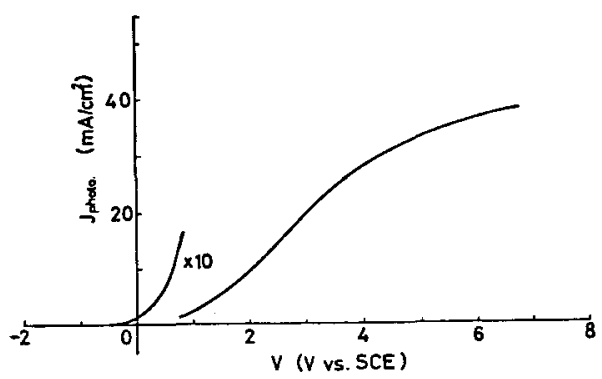

図 $7 \mathrm{Si}$-酸化鉄・人テロ接合型複合電極の電 流一電位特性（酸化鉄の膜厚方厚い場合）

$1.6 \mu \mathrm{m}$ 厚の酸化鉄膜を有する電極の光電流の波長依 存性を図 8 に示す. 図注量子效率（縦軸）を光の波長と 電位の関数として三次元的に示したものである.特徽的 なことは，波長約 $550 \mathrm{~nm}$ を境として，明確に2 種類の 異なった光応答が観測されるという点である。まず，電 位が $0.5 \mathrm{~V}$ 以下の弱いアノード分極領域では，550 nm より短波長でのみ光応答が観測される.電位が $0.5 \mathrm{~V}$ をこえると， $550 \mathrm{~nm}$ より長波長領域に，\&5一つの光

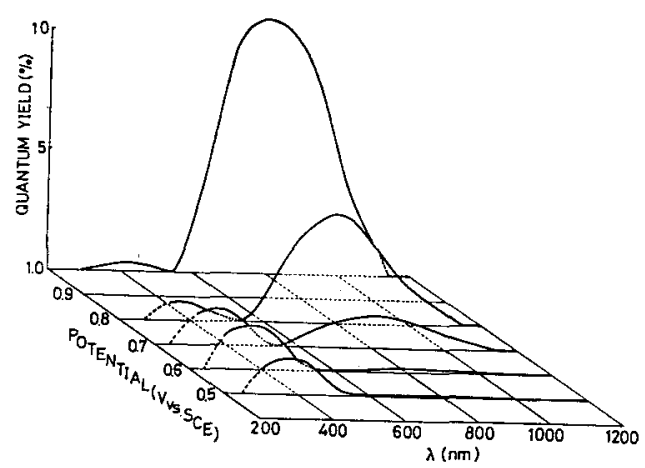

図 $8 \mathrm{Si}$-酸化鉄・ヘテロ接合型複合電極の光電流 の波長依存性（酸化鉄の膜厚が厚い場合） 
応答がみられるようになる。この応答は $550 \mathrm{~nm}$ から $1,140 \mathrm{~nm}$ にわたって分布しており，電位が增加するに つれて急激に量子効率が高くなっていく、これに反し て，短波長側のピークは電位の増加とともにむしろ減少 する傾向がある。

この長波長側の光応答は $\mathrm{Si}$ の応答に対応し，また， 短波長側のピークは，酸化鉄によるものである(吸収端 の $550 \mathrm{~nm}$ はバンドネャップ約 $2.2 \mathrm{eV}$ に相当してお り $\propto-\mathrm{Fe}_{2} \mathrm{O}_{3}$ によるもの).

酸化鉄-Si 複合構造電極がもつ高い量子効率は, $\mathrm{Si}$ 基 板から酸化鉄表面への正孔注入が非常に効率良く起こ。 ていることを示している. 以上のことから，この複合構 造電極では, Si と酸化鉄のへテロ接合が図 1 (b) の上 らに理想的なバンド構造になっているように推定される が、確実なことは今後の研究をまたねば分らない。

電極の安定性については, 酸化鉄膜厚が約 $200 \AA$ 以 上あれば，ほぼ問題ないことが分かっている．酸化鉄膜 厚 $300 \AA$ の試料について, IV (vs. SCE) にバイアス した状態で, 約 $0.1 \mathrm{~W} / \mathrm{cm}^{2}$ の光を照射し光電流を流し て一週間の耐久テストを行なった結果は，ほとんど光応 答特性の劣化は見られない。

\section{$4 \mathrm{TiO}_{2}-$ 太陽電池複合構造電極 ${ }^{3)}$}

まえがきに述べた研究目標の (3) は，外部補助電源な しに，光の力だけで動作することである．前節に紹介乙 たへテロ接合複合電極は (1)，(2) については非常に優 れた特性を示してたが，(3) については $\mathrm{TiO}_{2}$ に比べて かなり後退してしまった.

本多・藤嶋両氏による最初の水の光分解の害験では， $\mathrm{TiO}_{2}$ 陽極拉よび $\mathrm{Pt}$ 陰極をそれぞれ，アルカリおよび 酸性溶液に浸ける二槽式のむのだった。これをもし単一 槽に両極を浸ければ，外部電源を付加しなくては，水の 分解は行なわれない。

外部電源の補助なしに，ということは技術的内容とし ては，電極のフラットバンド電位が水素発生電位より負 であり，かつ起電力が十分に大であること，を意味す る. $\mathrm{SrTiO}_{3}$ などは，この条件にかなら材料だが，目標 (1)，(2) にかんして不満である.

ここに紹介する複合構造電極は, 主として外部電源の 排除沮いをもったものである. 図 9 亿示すようにp on $n$ 型太陽電池の表面に $\mathrm{TiO}_{2}$ の被膜を作る.この構 造の利点は，(a) 太陽電池の起電力を利用することによ り，表面層の $\mathrm{TiO}_{2}$ 膜に自動的にバイアスが加わる (b) $\mathrm{TiO}_{2}$ に泟用な長波長の光が太陽電池に有效に利 用される，の二点である. 図 10 注この電極の電流・電 位特性で, $\mathrm{TiO}_{2}$ に比べて $0.6 \mathrm{~V}$ ほどフラットバンド電 位が負にシフトしている. 白金を対極とした $0.1 \mathrm{M}-\mathrm{Na}$ $\mathrm{OH}$ 溶液の単一槽中で $1 \mathrm{~W} / \mathrm{cm}^{2}$ の白色光照射にり,

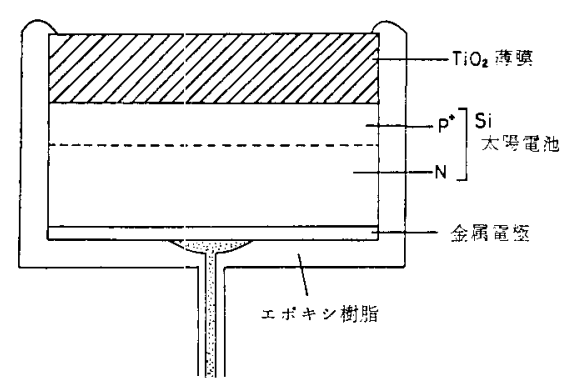

図 $9 \mathrm{TiC}_{2}$-太陽電池・複合構造電極

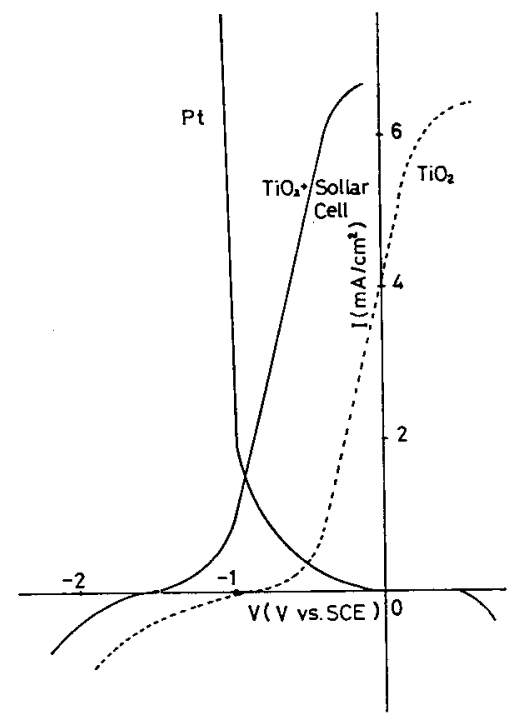

図 $10 \mathrm{TiO}_{2}$-太陽電池 ・複合構造電極 (実線), 乙 $\mathrm{TiO}_{2}$ (点線) の電流-電位特性

$2 \mathrm{~mA} / \mathrm{cm}^{2}$ の短絡電流が得られ, エネルギ一変換効率は $0.4 \%$ であった.

\section{5 おわりに}

理想的な半導体電極の開発を目指して, 被覆された半 導体電極として,どのような型のものが試みられてきた かを紹介した。ここに見た各種複合構造電極をささらに 複合することにより，すべての閒題点を克服すること も、できるかもしれない。

ただし，その際，複合化は複雑化であってはならな い.ここに紹介したものの単なる組合せで法なく，構造 的にはむしろ単純なものにしなくては，経済性の点で害 用にならないであるら．たとえば，4で見た電極も，現 在は原理的な分り易さのための第一段階として, 太陽電 池 ( $p-n$ 接合) の上に $\mathrm{TiO}_{2}$ (ヘテロ接合)を作ってい る.実際は，基体と被膜の作るへテロ接合が適当なるの であれば，基体内に别に $p-n$ 接合を作らなくとも，它 れだけでこの複合電極と同じ效果を持ら得るはずであ 
る、そしてそのへテロ接合が，さらに3で見た電極の例 のような特性を持ち合せたならば……...

われわれのなすべきことは多い。

\section{文献}

1) H. Morisaki, T. Baba and K. Yazawa, Observation of charge-transfer controlled photocurrennt at the $\mathrm{TiO}_{2}$-electrolyte interface, Phys. Rev. B 21, 837 (1980).
2) H. Morisaki, H. Ono, H. Dohkoshi and K. Yazawa, Iron-oxide coated $n-\mathrm{Si}$ as a heterostructure photoanode for the photoelectrolysis of water, $\mathrm{Ja}_{a}$ pan J. Appl. Phys. 19 (3), L 148 (1980).

3) H. Morisaki, T. Watanabe, M. Iwase and K. Yazawa, Photoelectrolysis of Water with $\mathrm{TiO}_{2}$-covered Solar Cell Electrodes, Appl. Phys. Letters. 29, 338 (1976).

\section{光源とその測定}

よく用いられる実験用光源に，(i) 白熱灯，(ii）け 、光灯，(iii) 水銀灯，(iv）キセノンアーク灯がある， (i) の発光の波長分布（スペクトけ）法フィラメント 温度で変わるが，通常用いられる号の（色温度2000 $3000 \mathrm{~K})$ では赤外部にピークをもち，可視部では波長 の增加とともに単調に増加する曲線となる。（ii）も用 いられるけい光体に依存するが，仃視全域に連続した スペクトルを持ち，その上に水銀による輝線 (436, $546 ， 578 \mathrm{~nm}$ ）が重疊している。笑験用，殺菌用に利 用されるケミカルランプまたはブラックライトは，外 観はけい光灯タイプであるが，紫外光を取り出す水銀 灯（低圧）である. (iii) は動作時の水銀圧力によって 低圧 $\left(\sim 10^{-3}\right.$ torr. $)$, 中圧 $(\sim 1 \mathrm{~atm})$, 高压 $(\sim 100 \mathrm{~atm})$ に区別される。低圧水銀灯はおもに $254 \mathrm{~nm}$ の輝線を 放出する.中压水銀灯で注 $366 \mathrm{~nm}$ の発光が主体で， さらに $313,405,436,546,578 \mathrm{~nm}$ 迋傍㲹も発光ピーク を示す，高圧水銀灯は，可視全域にわたるほぼ連続な スペクトルの上に，中圧灯と同じ発光波長に大きなピ 一クを持っている.（iv）浾外城汇強い発光 (825, $880 \mathrm{~nm}$ ) ほ加)を伴らが，可視域下゙法ほぼ平たんなス ペクトルを示すので，人工太陽に提せられるが，太陽 光は色温度 $5773 \mathrm{~K}$ の白熱灯にもっとも近いスペクト 儿分布を持っ。

単色光を得るには分光器の利用が理想的であるが, 強い光出力を要求するときにはフィルターを用いる. フィルターにはある波長以下をしゃ断するカットオフ 型と，特定波長範囲だけ透過する バンドパス 型があ り，後者の高精度のものに石英またはガラス板に薄膜 をサンドィッチして作った干渉フィルターがある。薄 膜内での光の干渉によって透過波長を選び出すので， ほぼ単色光と見なせる光が得られる。
物質にはそれぞれ固有の吸収スペクトルがあるが， 光電流，光起電力などは必ずしも吸収光量と比例しな い．それらの応答の大きさを波長に対してプロットし たグラフは，作用スペクトル (action spectrum) と呼 ばれる。

光強度の測定には，熱電対や半導体光電素子を利用 できる，前者は真空中の黑化金はくが光を吸収したと きの温度の上昇を検出するもので，波長によらず光の エネルギー強度を測定できるが感度が低い，最近よく 用いられているものは，光電流の直線性にすぐれたシ ヨトキー障壁型半導体素子を光検出器として用いた放 射計で，波長較正デー夕を付して市販されている．光 化学反忘の実験で吸光量を決定する際用いる化学光量 計は，光化学反応効率が既知の化合物 $(400 \mathrm{~nm}$ 以下 ではシュウ酸ウラニルやシュウ酸鉄カリウムをよく用 いる）の水溶液を石英セルに入れ，光照射後に反応生 成物を化学分析する。したがって光量を測定するむの であって，これを照射時間で割って光強度とするには 照射中の光強度の安定性が前提となる。

$$
\text { 败光ガルバニ電池 }
$$

\section{光ガルバニ電池}

色素（特に色素である必要はなく，光を吸収して作 用する物質であればよい）と，これに対して電子の授 受を行ないうる物質（電子供与体または受容体のいず れか）との混合系では，光を当てると光化学反店の生 存物が電極面の電気二重層に対して変化を与え，電位 変化をもたらす．このように，光エネルギーが光化学 反応を介して電気化学エネルギーに変換されらるデバ イスを光ガルバ二電池という，その代表例は次の通り である。

$$
\begin{array}{ll}
\mathrm{Pt} \mid \text { チオニン }-\mathrm{Fe}_{\mathrm{aq}} \mid & \mathrm{Pt} \\
\text { 明 } & \text { 暗 }
\end{array}
$$

